\title{
The chemistry and quality of water from the artesian wells of the Jurassic aquifer in Krakow
}

\author{
Katarzyna Chruszcz-Lipska ${ }^{1}$, Bogumiła Winid ${ }^{1}$, Michał Maruta ${ }^{1}$, \\ Antonina Chmura-Skirlińska ${ }^{2}$ \\ ${ }^{1}$ AGH University of Science and Technology, Faculty of Drilling, Oil and Gas; al. Mickiewicza 30, 30-059 Krakow, Poland;
e-mail:lipska@agh.edu.pl
${ }^{2}$ Jagiellonian University, Jagiellonian Centre for Experimental Therapeutics, ul. Bobrzyńskiego 14, 30-348 Krakow, Poland
}

(C) 2014 Authors. This is an open access publication, which can be used, distributed and reproduced in any medium according to the Creative Commons CC-BY 4.0 License requiring that the original work has been properly cited.

Received: 30 September 2014; accepted: 18 December 2014

\begin{abstract}
Selected quality parameters of groundwater from four artesian wells of the Jurassic aquifer located in the center of Krakow (Cracow) are presented. Water from these public wells i.e. Nadzieja, Jagielloński, Królewski and Lajkonik, during 20 years of exploitation, has had constant bacteriological purity and rather constant chemical composition. A comparison of nitrates concentration in the investigated wells with Quaternary wells located in the same area, and with municipal drinking water in Krakow shows that water from the above-mentioned four wells is characterized by the lowest concentration of $\mathrm{NO}_{3}{ }^{-}$ions. Very low nitrate and nitrite concentration suggests that despite passage of time the chemical composition of water from the investigated intakes is not affected by anthropogenic pollution because of isolation of water reservoir due to geological conditions.
\end{abstract}

Keywords: quality of groundwater, nitrate pollution, artesian well, Jurassic aquifer, Poland, Krakow

\section{INTRODUCTION}

Krakow is one of the oldest and largest cities in Poland. Its area of $326.8 \mathrm{~km}^{2}$ is inhabited by ca. 750,000 citizens. It is evident, that Krakow as a highly urbanized, industrial and city that attracts tourists has problems related to water and air pollution (Bokwa 2008). According to the World Health Organization (WHO) study Krakow has been rated amongst the most polluted cities in the world because of hazardous air quality. In that report, the old capital of Poland was ranked $8^{\text {th }}$ among 575 cities for levels of mass concentration of particles matter less than $2.5 \mu \mathrm{m}$ in size (PM 2.5) and $145^{\text {th }}$ among 1100 cities for levels of mass concentration of particles matter less than $10 \mu \mathrm{m}$ in size (PM 10). The very high concentrations of these factors are the result of both very high emissions and the location of Krakow in a topographic basin which drastically hampers the natural ventillation of the city (Bokwa 2008). Also the quality of drinking water has been a problem for a long time for citizens of Krakow. The oldest municipal plant supplied water from the Vistula River. In the 60's the city reduced and in 1988 finally stopped using intakes localized on the Vistula River because of its high level of pollution (Wodociagi Krakowskie. Raport roczny 2013). It was also shown that, the Vistula River, the most important river in Poland, whose basin covers ca. $54 \%$ of the country, is the most polluted river in the macroregion of Krakow (Buszewski et al. 2005). At present, drinking water in Krakow is collected, treated and supplied by four water treatment plants. Krakow's tap water originates almost solely from surface waters (97\%) from tributaries of the Vistula River i.e. Sanka, Rudawa, Dłubnia and the artificial Lake Dobczyce on the Raba River (a tributary of the Vistula River). 


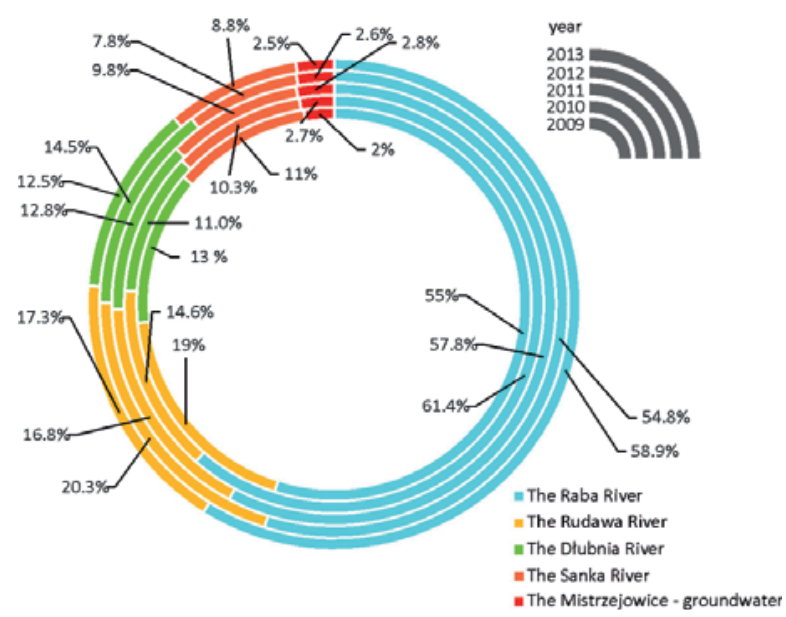

Figure 1. Main sources of drinking water in Krakow, years 2009-2013 (according to Woda i My 2006-2013)

Only about $3 \%$ of the supplied water originates from groundwater sources (Fig. 1). Nowadays, Municipal Waterworks and Sewer Enterprise in Krakow Joint Stock Company persuade that tap water has very good quality and is safe for direct consumption. Nevertheless, despite broad and rigid laboratory controls in water treatment plants, some atypical substances may enter without control to municipal water because the assessment procedure of water quality according to the existing regulations does not take into account all possible pollutants. An example may be the caffeine detection, originated from sewage, in the Rudawa River basin, including the area of municipal intake in the range from 0.04 to $0.38 \mathrm{mg} / \mathrm{L}$ (Jagoda et al. 2013).

In the area of Krakow there is a serious threat of groundwater contamination due to anthropogenic factors. The amount of groundwater in relation to needs is not sufficient. Existing groundwater resources should therefore be rationally used and protected.

The history of the artesian wells investigated in this work (Nadzieja, Jagielloński, Królewski and Lajkonik) starts in the 80's and is connected with the concept of underground construction in Krakow. At that time several boreholes were sunk within the complicated geological structure of the Krakow City Center. Finally, as an effect of drilling, geophysical and other exploration work, a few artesian public wells located in the confined Jurassic carbonate fractured aquifer were designed, built and put into service in the early 90's (Kleczkowski et al. 1994, Myszka \& Gołda 2003). Thus, the construction of wells is a good example of the direct or indirect use of exploration drilling for other than intended purposes and shows a huge potential which can be included in each new borehole.

Despite the fact, that values of selected parameters of groundwater from Nadzieja, Jagielloński, Królewski and Lajkonik artesian wells are higher than the quality standards for drinking water (Rozporzadzenie Ministra Zdrowia $z$ dnia 29 marca 2007 r. w sprawie jakości wody przeznaczonej do spożycia przez ludzi, Rozporządzenie Ministra Zdrowia $z$ dnia 20 kwietnia 2010 r. zmieniające rozporzadzenie w sprawie jakości wody przeznaczonej do spozycia przez ludzi, Directive 98/83/EEC of the European Parliament and of the Council of 3 November 1998), water from these wells is recognized as safe and beneficial to human health (Kleczkowski et al. 1994) and belongs to Krakow's public network of wells which can be used as an alternative water source for human consumption.

The main goal of this paper is the study of changes of water quality in the most commonly used of Krakow's artesian wells of the Jurassic aquifer from the beginning of their exploitation to nowadays. In particular, nitrates concentration as a marker of anthropogenic pollution in water was investigated. Our results and the data obtained by two certified Krakow laboratories were collected and discussed.

\section{CHARACTERISTICS OF THE HYDROGEOLOGICAL CONDITIONS IN THE STUDY AREA AND THE INVESTIGATING WATERS}

Krakow is situated at the borders of large tectonic units: the Silesian-Krakow Monocline, Miechów Synclinorium and Carpathian Foredeep. The area consists of carbonate deposit of Jurassic, Cretaceous, Tertiary and Quaternary in age (Kleczkowski et al. 1994). The complicated geological structure in the area of Krakow is related to the presence of numerous horsts and grabens formed during the Alpine orogenic movements (Fig. 2). There are four aquifers (Jurassic, Cretaceous, Tertiary and Quaternary) but only two them (Jurassic and Quaternary) are essential for the problem discussed in this paper. The Jurassic aquifer is represented mainly by the Oxfordian limestones which 


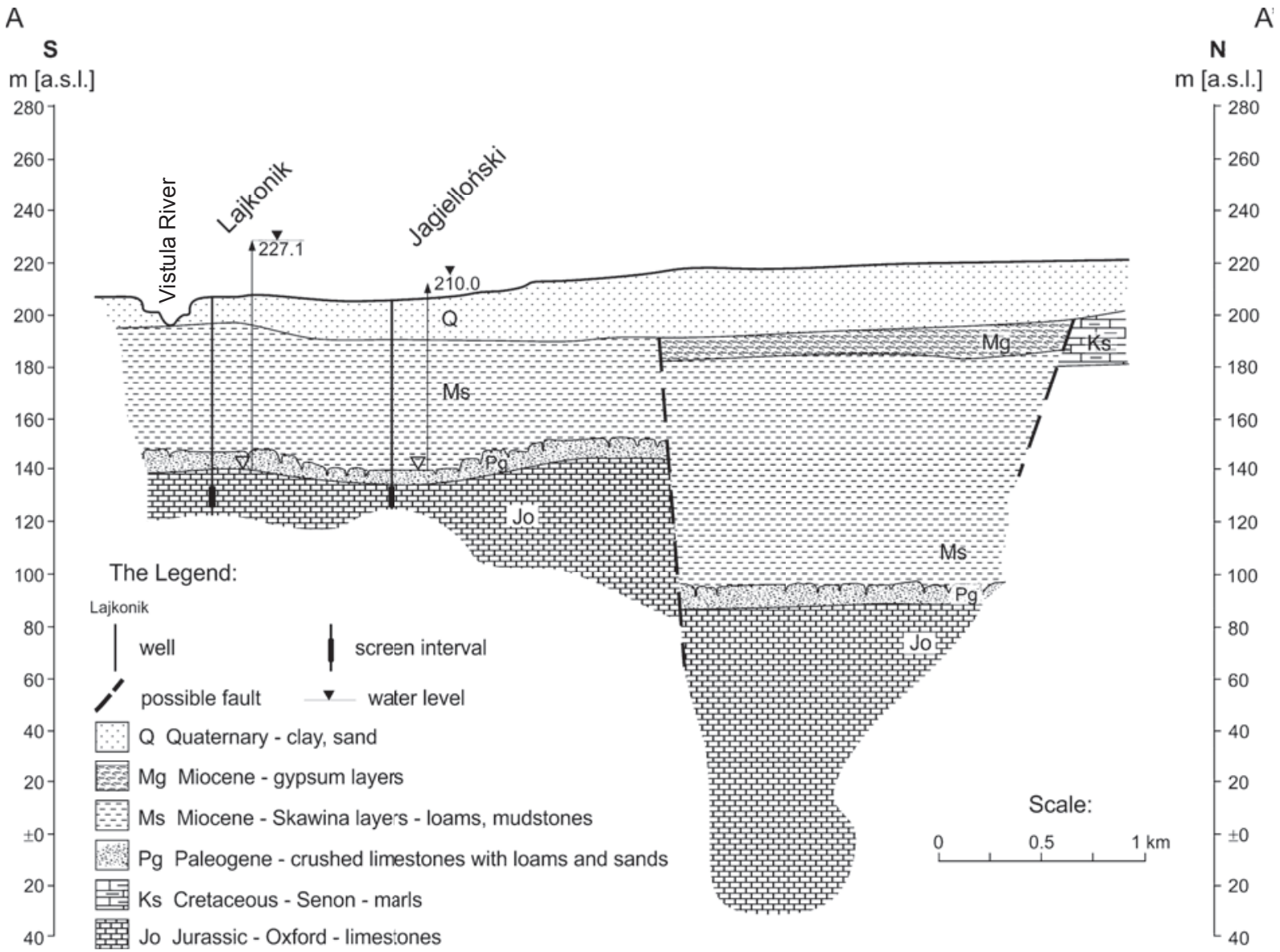

Figure 2. Hydrogeological cross-section across two of the investigated artesian wells Lajkonik and Jagiellonski (after Kleczkowski et al. 1994, modified)

are rich in karts features. The thickness of the limestone ranges from 65 to $293 \mathrm{~m}$. The geological structure of these deposits has an important impact on the groundwater flow. Due to numerous faults, the water level is stabilized at various depths. The values of hydraulic conductivity for the Upper Jurassic aquifer range from $2.62 \cdot 10^{-9}$ to $1.40 \cdot 10^{-3} \mathrm{~m} / \mathrm{s}$ (Józefko \& Motyka 1993). In the area, where the Upper Jurassic deposit area is isolated by Miocene clays, water filling tectonic grabens flows under artesian pressure (Fig. 2). The thickness of Miocene clay in the study area is in the range from about 20 to $50 \mathrm{~m}$. The Cretaceous aquifer is connected with marls and gaizes (Senonian) and arenaceous and organogenic limestones with conglomerates (Cenomanian and Turonian) (Rutkowski 1989). The Tertiary aquifer consists of Miocene sands. The Quaternary aquifer consists of fluvial sands and gravels, the sediments reach the maximum thickness of 10-15 $\mathrm{m}$ (Kleczkowski 1989). The values of hydraulic conductivity for the Quaternary aquifer range from 1.0 to $2.0 \cdot 10^{-4} \mathrm{~m} / \mathrm{s}$
(Duda et al. 1997). The deposits are partially overlain by anthropogenic soils, accumulated during centuries of human activity. Thus, a large number of the contaminant sources can influence the chemical composition of the shallow Quaternary aquifer in the Krakow area (Kleczkowski et al. 2009).

Groundwater in the area of Krakow is present within two zones. The upper zone is related to with Quaternary deposits and shallow Cretaceous and Jurassic carbonates. The lower zone of the groundwater occurs below the impermeable Miocene clays within Mesozoic carbonate rocks and Tertiary deposits. Recharge of the unconfined aquifer is directly by precipitation but recharge of the lower zone is from the South West region of the study area. The Krakow area is drained by the Vistula River and recharged in two different ways, namely by lateral inflow of the surface water from the Vistula valley, and by infiltration of precipitation (Zuber et al. 2004). Tectonic dislocation may be a hydraulic contact for the aquifers. 
The age of studied groundwater from artesian wells: Nadzieja, Królewski and Lajkonik wells was estimated to be ca. 10000 years (Kleczkowski et al. 1994). On the basis of isotopic measurements it was determined that there are glacial waters and that water from the Lajkonik well is the oldest (Zuber \& Grabczak 1991, Grabczak \& Zuber 1992, Motyka \& Zuber 1992, Osenbrück et al. 1993). The research results from the 90's also showed that this groundwater is not affected by anthropogenic pollutions, is poorly renewable and the reserve is relatively small (Kleczkowski et al. 1994). Although, the waters from the wells have the same origin and the distances between them are short, there are small differences between chemical compositions of water from each intake. It is due to the fact that each well exploits a resource located in isolated tectonic blocks of Jurassic aquifer (Kleczkowski et al. 1994, Myszka \& Gołda 2003).

\section{METHODS}

\section{Analyses of water quality}

Analyses of physical, chemical and microbiological parameters of water samples were done by two independent Krakow laboratories i.e. Sanitary-Epidemiological Facility (WSSE, Kraków) and Central Laboratory of Municipal Waterworks and Sewer Enterprise (MPWiK SA, Kraków).
Table 1

Analytical methods applied for detection of selected parameter of water quality

\begin{tabular}{|l|l|}
\hline \multicolumn{1}{|c|}{ Parameter } & \multicolumn{1}{c|}{ Analytical method } \\
\hline Turbidity & Nefelometric \\
\hline $\mathrm{pH}$ & Potentiometric \\
\hline Electroconductivity (EC) & Conductometric \\
\hline $\mathrm{NO}_{3}^{-}, \mathrm{NO}_{2}^{-}, \mathrm{SO}_{4}^{2-}$ & Ion hromatography \\
\hline $\mathrm{Fe}, \mathrm{NH}_{3}$ & UV/Vis Spectroscopy \\
\hline $\begin{array}{l}\mathrm{Ca}, \mathrm{Mg}^{2-} \mathrm{Cl}^{-}, \text {alkalinity } \\
\text { as } \mathrm{CaCO}\end{array}$ & Titration \\
\hline $\begin{array}{l}\mathrm{K}, \mathrm{Na}, \mathrm{Mn}^{-} \\
\text {Escherichia coli, } \\
\begin{array}{l}\text { Escherichia coli group, } \\
\text { Enterococci }\end{array}\end{array}$ & $\begin{array}{l}\text { Atomic Absorption } \\
\text { Spectrometry }\end{array}$ \\
\hline
\end{tabular}

Both these laboratories are certificated and use the same procedures according to the required standards. The applied analytical methods are listed in Table 1.

The results obtained by both laboratories are consistent, and only some discrepancies were observed, especially in the values of nitrate concentrations. The results of the chemical analyses for 80 samples of groundwater ( 20 for each well) are shown in the part IIA of Table 2.

Table 2

Part I: the technical data of the studied artesian wells. Part II: the comparison of selected physical, chemical and microbiological parameters of water from artesian wells of the Upper Jurassic aquifer

\begin{tabular}{|c|c|c|c|c|c|}
\hline \multirow{2}{*}{ Characteristics } & \multicolumn{4}{|c|}{ Name of the well } & \multirow{2}{*}{$\begin{array}{c}\text { MAC } \\
\text { for drinking } \\
\text { water }^{\mathrm{B}}\end{array}$} \\
\hline & Nadzieja & Królewski & Jagielloński & Lajkonik & \\
\hline \multicolumn{6}{|c|}{ PART I ${ }^{A}$} \\
\hline Date of the exploitation beginning & $\begin{array}{l}5 \text { April } \\
1990\end{array}$ & $\begin{array}{c}5 \text { December } \\
1990\end{array}$ & $\begin{array}{c}4 \text { October } \\
1993\end{array}$ & $\begin{array}{c}26 \text { March } \\
1992\end{array}$ & - \\
\hline $\begin{array}{l}\text { Elevation } \\
\text { [m a.s.l.] }\end{array}$ & 211.8 & 206.0 & 204.0 & 205.1 & - \\
\hline $\begin{array}{l}\text { Depth of well } \\
{[\mathrm{m}]}\end{array}$ & 81.0 & 85.0 & 80.0 & 83.0 & - \\
\hline $\begin{array}{l}\text { Depression } \\
{[\mathrm{m}]}\end{array}$ & 16.0 & 16.0 & $\sim 5.5$ & $\sim 21.0$ & - \\
\hline $\begin{array}{l}\text { Discharge } \\
{\left[\mathrm{m}^{3} / \mathrm{h}\right]}\end{array}$ & 0.367 & 1.533 & 0.55 & 0.338 & - \\
\hline
\end{tabular}


Table 2 cont.

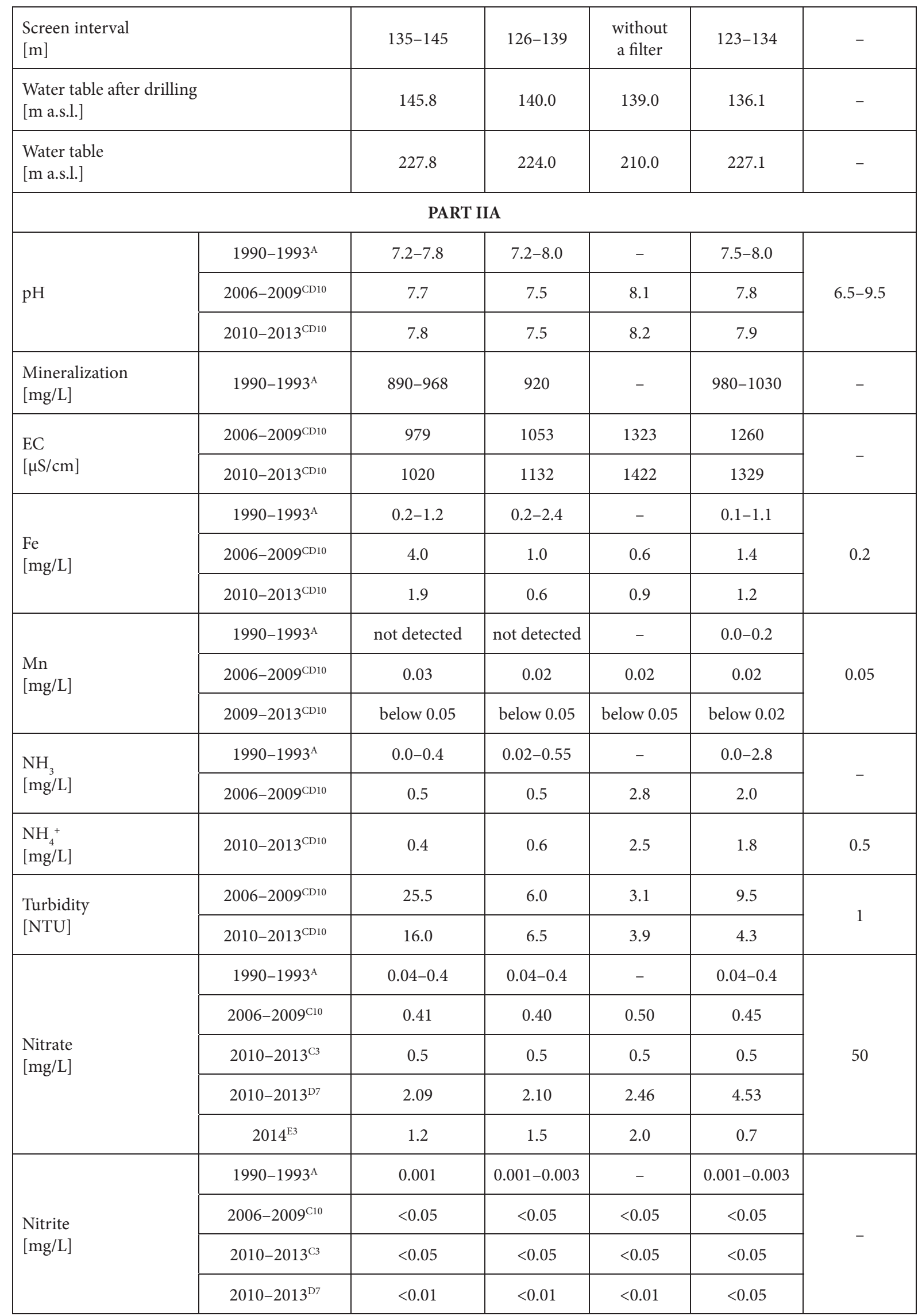


Table 2 cont.

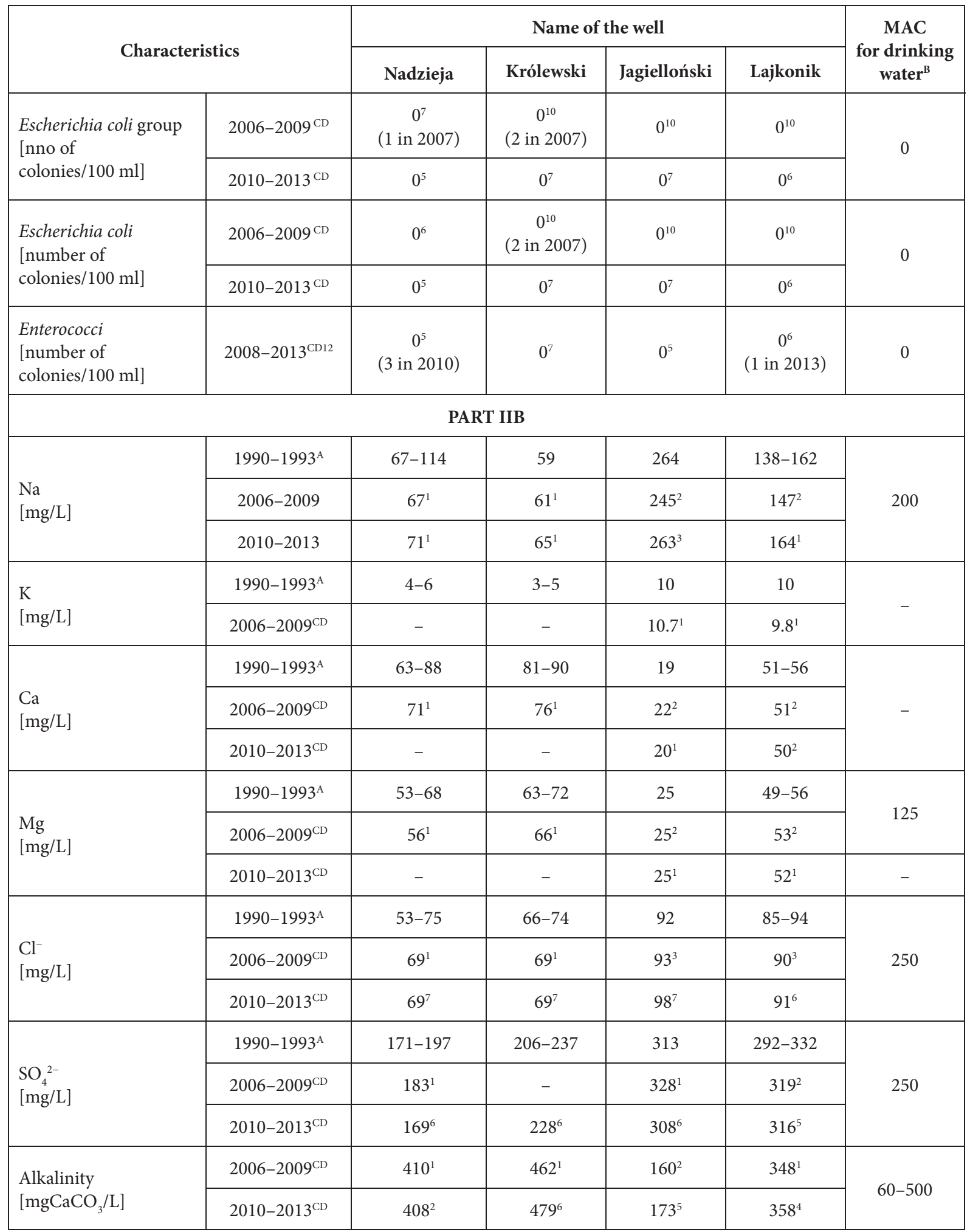

Explanations:

A - according to Kleczkowski et al. 1994,

в - MAC (maximal accessible concentration) according to Journal of Laws No 61, item 417, of 29 March 2007, Minister of Health, Poland,

C - data from WSSE, Kraków,

D - data from MPWiK SA, Kraków

E - our measurements by chemiluminescent method,

$1,2,3 .$. - quantity of population for estimation of mean value. 


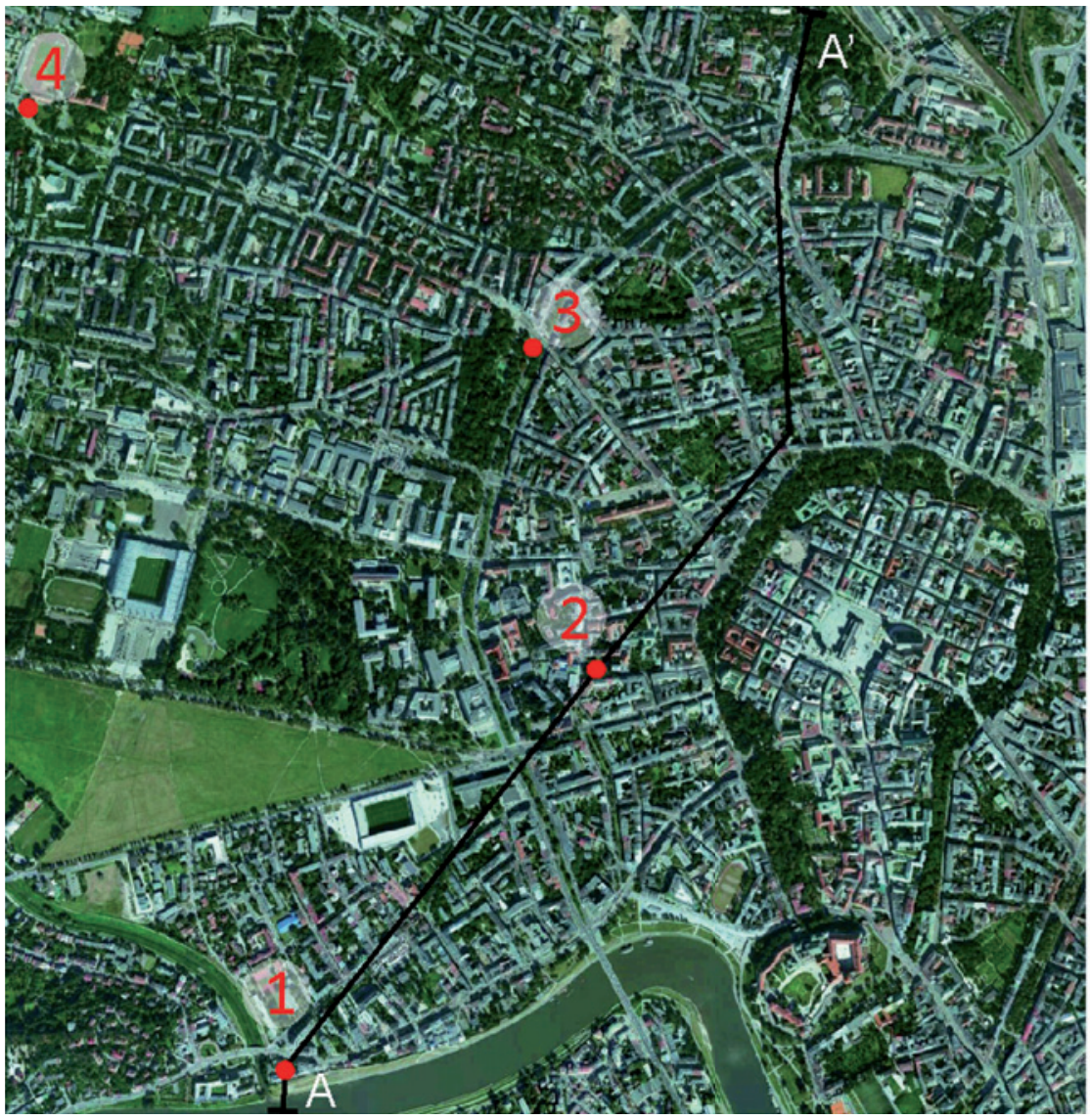

The Legend:

- artesian wells:

1- Lajkonik

2- Jagielloński

3- Królewski

4- Nadzieja

$\overbrace{}^{A}$ - hydrogeological cross-section

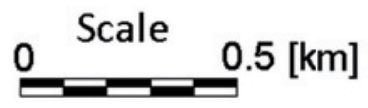

Figure 3. Localization of sampling places (after Google Earth and Kleczkowski et al. 1994, modified)

Part IIB of Table 2 includes additional results obtained for lower quantity of samples.

Water samples from the artesian wells were examined in the year range of 2006-2013 and the sampling localities are presented in Figure 3. The technical data of the studied wells are summarized in part I of Table 2

\section{Measurements of nitrate concentration by chemiluminescent method and using an ENO-20 NOx analyzer}

Sampling was done by us using the protocol for groundwater monitoring (PN-ISO ISO 5667-3: 2005). Next, samples were transported to the laboratory at $4^{\circ} \mathrm{C}$ temperature. Measurements of the nitrate concentration were conducted by us immediately after delivery to the laboratory. The nitrite and nitrate concentration after back reduction to $\mathrm{NO}$ was measured using gas-phase chemiluminescent reaction between $\mathrm{NO}$ and ozone using Sievers ${ }^{\star}$ Nitric Oxide Analyzer NOA $280 \mathrm{i}$. The reduction of nitrites was performed in a closed glass chamber containing a reducing agent ( $1 \% \mathrm{wt} / \mathrm{vol}$ of $\mathrm{KI}$ in acetic acid) to convert nitrite to nitric oxide. The independent calibration on fresh $\mathrm{NaNO}_{2}$ standard solution was done according to the manufacturer instruction (Sievers* Nitric Oxide Analyzer NOA 280i) for every experiment before measurements series of samples. To measure nitrate, vanadium (III) chloride in hydrochloric acid was used to convert nitrate to nitric oxide.

Additionally, the nitrate was measured using an ENO-20 NOx analyzer (Eicom USA). The ENO-30 system is a specialized HPLC for separating and detecting nitrite and nitrate.

\section{RESULTS AND DISCUSSION}

\section{The chemistry and quality of groundwater}

Nowadays, the need for monitoring of drinking water quality is evident. According to literature, the first examination of water quality in Krakow was done in the second part of the $19^{\text {th }}$ century. 
The waters from many wells of the city were investigated in that time in the context of both chemical and microbiological composition. The first study was done in 1871 by Karol Olszewski, the world famous scientist who was the first to liquefy oxygen and nitrogen (Olszewski 1871, Czop et al. 2010).

The analyses of water (Kleczkowski et al. 1994) from the investigated intakes (mineralization and electroconductivity (EC)) indicate that they belong to acratopegaes (Tab. 2). Water from these wells is multi-ion type. Water from Nadzieja and Królews$k i$ are classified as five-ion: $\mathrm{HCO}_{3}-\mathrm{SO}_{4}-\mathrm{Mg}-\mathrm{Na}-\mathrm{Ca}$, from Lajkonik as $\mathrm{Na}-\mathrm{SO}_{4}-\mathrm{HCO}_{3}-\mathrm{Mg}-\mathrm{Cl}$ and from Jagielloński well as four-ion: $\mathrm{Na}-\mathrm{SO}_{4}-\mathrm{HCO}_{3}-\mathrm{Cl}$ (Kleczkowski et al. 1994).

According to the relevant Polish Regulation (Rozporzadzenie Ministra Zdrowia $z$ dnia 29 marca 2007 r. w sprawie jakości wody przeznaczonej do spożycia przez ludzi, Rozporzadzenie Ministra Zdrowia $z$ dnia 20 kwietnia 2010 r. zmieniajace rozporządzenie w sprawie jakości wody przeznaczonej do spożycia przez ludzi) and the WHO recommendation, selected parameters of the investigated waters like turbidity and $\mathrm{Fe}, \mathrm{Mn}, \mathrm{Na}$ or sulphate ions concentration are exceeded in some cases in comparison to standards for drinking water.

Turbidity is a principal physical characteristic of water and is not desirable in drinking water and in many manufacturing uses. Unfortunately, the values of turbidity are relatively high and not stable in the investigated wells. According to previous studies it is caused by two different factors. One of them is connected with the geology of the Krakow area. As mentioned above, there is a large amount of iron and manganese ions in the investigated waters. The second factor is related to the construction of the wells and possible corrosion of their steel elements (Myszka \& Gołda 2003, Szczepańska et al. 2008). It was shown that after renovation and change of steel filter in the Królewski well in 2002, the values of two unstable parameters of water turbidity and iron concentration were reduced significantly and stabilized (Myszka \& Gołda 2003, Szczepańska et al. 2008). Excessive turbidity may cause health problems, because it can provide nutrients and shelter for pathogens in the next step their spawning (LeChevallier et al. 1991). However, the turbidity of water of the investigated wells seems to be only an aesthetic problem. The water is not clear due to the presence of inorganic matter like precipitates of iron and manganese which are not typically a health hazard in drinking water (Prasad \& Danso-Amoako 2014).

One of the biggest advantages of water from the investigated wells is constant bacteriological cleanliness. According to the new Polish Regulation which refers to monitoring of protected surface and groundwater (Rozporzadzenie Ministra Środowiska $z$ dnia 21 listopada 2013 r. zmieniajace rozporzadzenie $w$ sprawie form $i$ sposobu prowadzenia monitoringu jednolitych części wód powierzchniowych i podziemnych) three microbiological indicators should be measured: Escherichia coli, Escherichia coli group and Enterococci. The first two markers were measured starting from the year 2006 and all of these three markers have been measured since 2008. As is seen in Table 2 the values were permanently equal to 0 and only few not important episodes were identified. Other benefits of water from the investigated wells are very low levels of nitrate and nitrite concentrations. Relatively small values of ammonium ions originate from inorganic matter which is connected with genesis of Miocene deposits (Kleczkowski et al. 1994). Additionally, water from these wells contains large amounts of magnesium and fluoride ions (ca. $1.5 \mathrm{mg} / \mathrm{L}$ ). Also, the occurrence of some microelements like $\mathrm{Sr}, \mathrm{Li}$ or B was recognized as valuable (Kleczkowski et al. 1994).

Contamination of water with some metals is one of the most important issues in the modern world (Kumar et al. 2012, Agca et al. 2014). Although, metals like zinc or copper are microelements essential to humans, in large quantities they may cause serious health problems. On the other hand, metals such cadmium, lead or chromium are highly toxic even in low concentration (Alam et al. 2012). Our data indicate that concentrations of selected relevant metal ions in waters from investigated wells are at low level. For instance, for the Lajkonik well, located in close to the Vistula River, concentrations of ions: $\mathrm{Cr}, \mathrm{Cd}, \mathrm{Cu}, \mathrm{Ni}, \mathrm{Pb}$ and $\mathrm{Hg}$ equal $<0.002,<0.0004,0.04,<0.012,<0.004$ and $<0.0005 \mathrm{mg} / \mathrm{L}$, respectively.

\section{Concentration of nitrate}

Nitrogen may be present in water as various dissolved inorganic species: nitrate $\left(\mathrm{NO}_{3}^{-}\right)$, ammonium $\left(\mathrm{NH}_{4}^{+}\right)$, nitrite $\left(\mathrm{NO}_{2}^{-}\right)$and nitrogen gas $\left(\mathrm{N}_{2}\right)$. 
In aquatic environments the nitrate ion occurs in the stable form and variations in its natural baseline concentrations are large. Some aquifers have median concentrations greater than maximum admissible concentration $(50 \mathrm{mg} / \mathrm{L})$ according to the regulation existing in Poland and European Union. However, changes of $\mathrm{NO}_{3}$ concentrations in both surface and ground waters are predominantly caused by human activities (Edmunds \& Shand 2008, Buccianti et al. 2014). Water pollution by nitrate is a common problem of the modern world. In the agricultural area nitrification of fertilizer and sewage are the main sources of nitrate (Georgieva et al. 2010). In the urban resort contamination may arise from diffuse sources such as airborne dust, rainfall, as well as from point sources, which may include contaminated rivers, sewage outflows or dumping sites. Approximately $46.7 \%$ of the surface water samples and $10 \%$ of the groundwater samples exceeded the World Health Organization (WHO) drinking water standard for $\mathrm{NO}_{3}-\mathrm{N}$ (Zhang et al. 2014). While, nitrogen is an essential nutrient for cultivated plants and influences crops, its high concentration can be harmful to humans and nature. Contamination of water by nitrate is an important issue, because high concentration of $\mathrm{NO}_{3}{ }^{-}$ions can lead to death of infants by methemoglobinemia or gastric carcinomas (Agca et al. 2014). The European Union even dedicated a special Nitrate Directive 91/676/ EEC to protect waters against pollution by nitrates from agricultural sources.

In that context, nitrates concentration can be used as a marker of anthropogenic pollution for investigated wells. In Figure 4 a comparison of nitrate content of water from investigated artesian wells with water from Quaternary wells in the centre of Krakow and also municipal water is presented. For the better visualization of the dataset, the vertical axis has two ranges with two different scales (the logarithmic scale in the range of values from 0.1 to $10 \mathrm{mg} / \mathrm{L}$ and the linear scale above $10 \mathrm{mg} / \mathrm{L}$ ). As is presented in Figure 4 nitrates concentration in water from the investigated artesian wells is the lowest one. Surprisingly, some noticeable differences in determination of nitrate concentration in 2011 and 2012 between two independent laboratories are observed. Both of them are certified and used the same liquid chromatography measurement procedures according to international standard ISO 10304.

The data obtained by us using a sensitive chemiluminescence method, show that the concentration of nitrate ions in 2014 is in the range of $0.7-2.0 \mathrm{mg} / \mathrm{L}$ and mean value equals: $2.0,1.5,1.2$ and $0.7 \mathrm{mg} / \mathrm{L}$ for wells Jagielloński, Królewski, Nadzieja and Lajkonik, respectively. It is worth mentioning, that the reference chromatographic method gives us, for the same set of water samples, a slightly smaller final values i.e. $1 \mathrm{mg} / \mathrm{L} \mathrm{NO}_{3}{ }^{-}$ for Jagiellonski well and $<1 \mathrm{mg} / \mathrm{L}$ for the other Jurassic artesian wells. Thus, the selection of a correct procedure for the detection and analysis of nitrate and/or nitrite among the vast diversity of methods currently available (Moorcroft et al. 2001) for appropriate samples is very important. Our experimental results indicate that the chemiluminescence methodology is better for assessment of nitrate for such samples with small content of nitrates.

To conclude, the nitrates concentration in all investigated wells is at a low level. Data from WSSE in Krakow show that the nitrate concentrations during the whole 2006-2013 period are below $1 \mathrm{mg} / \mathrm{L}$. Our measurements confirmed also the small content of nitrate. According to literature (Kleczkowski et al. 1994), nitrates concentrations were very low at the beginning of exploitation and equal about $0.4 \mathrm{mg} / \mathrm{L}$, however the experimental procedure is unknown and comparison to the current results is difficult.

In contrast to the results for the artesian wells the highest values of nitrates concentrations were observed in the Quaternary wells located in their close vicinity in the centre of Krakow. Two of the results exceeded maximal accessible concentration and are located out of scale in Figure 4. This figure also illustrates, that the $\mathrm{NO}_{3}{ }^{-}$concentration in the municipal water (after treatment) is generally in the range of $7-25 \mathrm{mg} / \mathrm{L}$ and is dependent on water treatment plants. During the whole investigated period of time the lowest values are detected in water from the artificial lake Dobczyce (the Raba River).

The presented data concerning nitrate concentration confirm that water from the investigated artesian wells is not influenced by anthropogenic pollutions. 


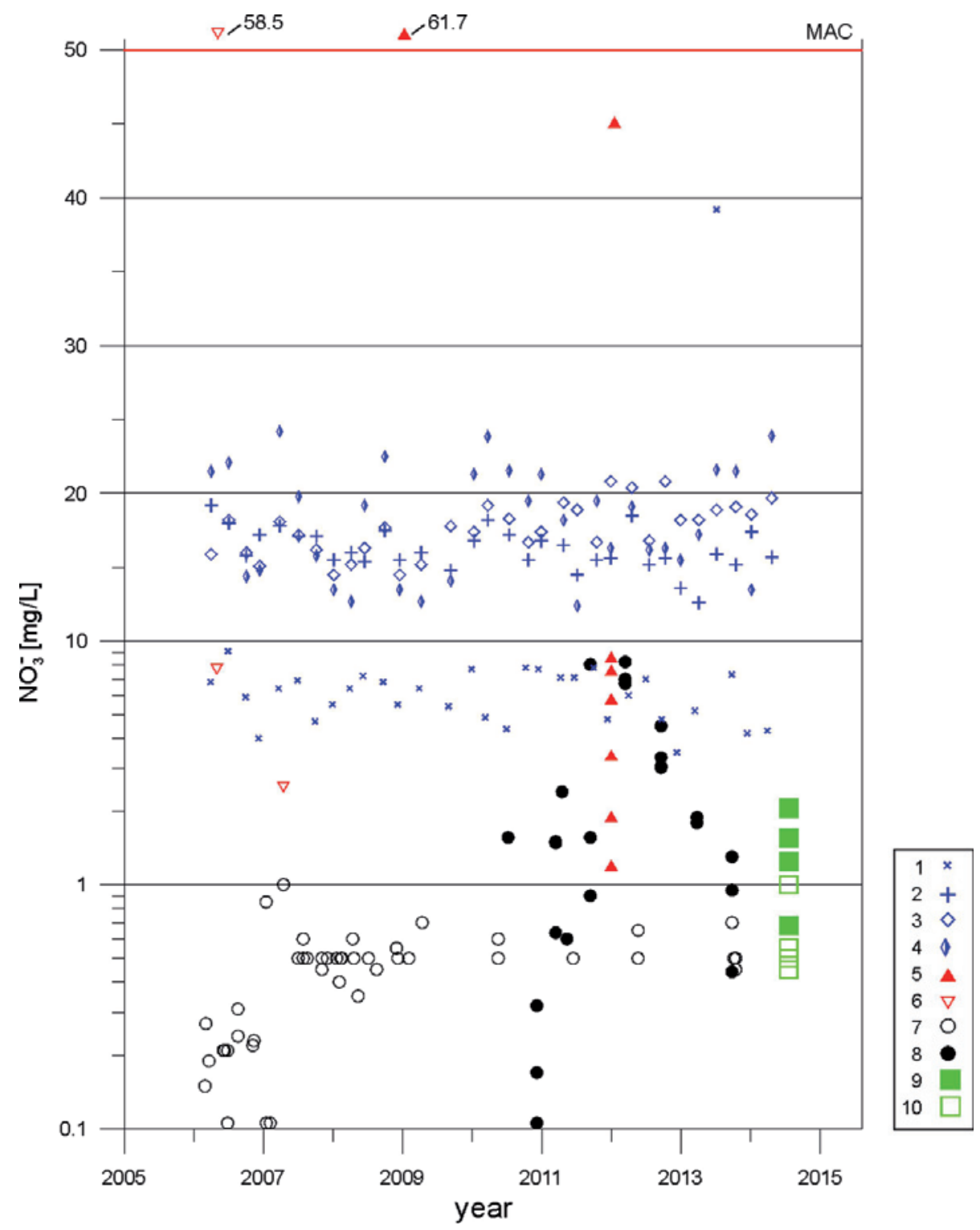

Figure 4. The nitrate concentration in the water intakes in Krakow, years 2006-2014. The municipal water (according to Woda i My 2006-2013): 1 - the Raba River, 2 - the Rudawa River, 3 - the Dtubnia River, 4 - the Sanka River; the Quaternary water: 5 - according to Kasprzak et al. 2013, 6 - according to Wodociagi Krakowskie. Raport roczny 2013, Kraków; investigated artesian wells of the Jurassic aquifer: 7 - according to WSSE, Kraków, 8 - according to MPWiK SA, Kraków and our measurements: 9 - chemiluminescence method, 10 - chromatography method. For the better visualization of the dataset, the vertical axis has two ranges with two different scales (the logarithmic scale in the range of values from 0.1 to $10 \mathrm{mg} / \mathrm{L}$ and the linear scale above $10 \mathrm{mg} / \mathrm{L}$ )

\section{CONCLUSIONS}

Drinking water in Krakow is produced almost entirely from surface waters supplied by from tributaries of the largest river in Poland, the Vistula River. This type of water can be very strongly affected by anthropogenic pollution in such a highly urbanized and industrial area. In this context, reservoirs of pure groundwater are very valuable as water supplies for human consumption and should be protected. Their protection requires active monitoring to identify the sources of water pollution and the determination of concentration and mobility of potential contaminating substances.

The investigations of groundwater from artesian wells in Krakow City Centre show stability of water parameters during the whole period of exploitation. Results obtained by two certified laboratories and our measurements show low levels of nitrate and nitrite concentration in the water. Additionally, concentrations of selected relevant 
heavy metal ions are at a low level. These findings indicate that despite the passage of time the investigated water reservoir of the Jurassic aquifer is still isolated from anthropogenic pollution and the citizens of Krakow have the opportunity to drink pure water which the age of which was determined ca. 10,000 years.

The research work was supported under the AGH University of Science and Technology Research Programs no 11.11.190.555.

\section{REFERENCES}

Agca N., Karanlik S. \& Odemis B., 2014. Assessment of ammonium, nitrate, phosphate, and heavy metal pollution in groundwater from Amik Plain, southern Turkey. Environmental Monitoring and Assessment, 10.1007/ s10661-014-3829-z.

Alam M., Rais S. \& Aslam M., 2012. Hydrochemical investigation and quality assessment of groundwater in rural areas of Delhi, India. Environmental Earth Sciences, 66, 97-110.

Bokwa A., 2008. Environmental impacts of long-term air pollution changes in Kraków, Poland. Polish Journal of Environmental Studies, 17, 5, 673-686.

Buccianti A., Nisi B., Martin-Fernandez J.A. \& Palarea-Albaladejo J., 2014. Methods to investigate the geochemistry of groundwaters with values for nitrogen compounds below the detection limit. Journal of Geochemical Exploration, 141, 78-88.

Buszewski B., Buszewska T., Chmarzyński A., Kowalkowski T., Kowalska J., Kosobucki P., Zbytniewski R., Namieśnik J., Kot-Wasik A., Pacyna J. \& Panasiuk D., 2005. The present condition of the Vistula river catchment area and its impact on the Baltic Sea coastal zone. Regional Environmental Change, 5, 97-110.

Council Directive 91/676/EEC of 12 December 1991 concerning the protection of waters against pollution caused by nitrates from agricultural sources. Official Journal of the European Communities L 375/1, 31.12.91

Council Directive 98/83/EC of 3 November 1998 on the quality of water intended for human consumption. Official Journal of the European Communities L 330/32, 5.12 .98

Czop M., Motyka J., Wardas-Lasoń M. \& Tabaszewski W., 2010. Warunki hydrogeologiczne rejonu Rynku Głównego w Krakowie. Krzysztofory. Zeszyty Naukowe Mu zeum Historycznego Miasta Krakowa, 28, 2, 163-176.

Duda R., Haładus A. \& Witczak S., 1997. Mapa hydrogeologiczna Polski w skali 1:50 000. Arkusz Kraków (973). Państwowy Instytut Geologiczny, Warszawa.

Edmunds W.M. \& Shand P. (ed.), 2008. Natural Groundwater Quality. Blackwell Publishing Ltd

Georgieva N., Yaneva Z. \& Dospatliev L., 2010. Ecological monitoring of the fresh waters in Stara Zagora Region, Bulgaria I. Quality analyses of nitrogen compounds contents. Desalination, 264, 48-55.
Grabczak J. \& Zuber A., 1992. Skład izotopowy i wiek wód artezyjskich w wapieniach jurajskich na obszarze Krakowa. [in:] Kowalski J. (red.), Problemy hydrogeologiczne południowo-zachodniej Polski, Sudety, Wrocław, $127-130$.

Jagoda A., Żukowski W. \& Dąbrowska B., 2013. Presence of caffeine in the Rudawa River and its tributaries. Proceedings of ECOpole, 7, 1, 87-91.

Józefko I. \& Motyka J., 1993. Wodoprzepuszczalność skał górnej kredy i górnej jury w rejonie Krakowa. [in:] Poprawski L. \& Bocheńska T. (red.), Współczesne problemy hydrogeologii: VI [spotkanie naukowe polskich hydrogeologów, Polanica-Zdrój 1993 r.], Sudety, Wrocław, 73-78.

Kasprzak A., Motyka J. \& Wardas-Lasoń M., 2013. Changes in the chemical composition of groundwater in quaternary aquifer in old Krakow, Poland (years 2001-2012). Geology, Geophysics \& Environment, 39, 2, 143-152.

Kleczkowski A.S., 1989. Szkic zagadnień hydrogeologicznych Krakowa. Przeglad Geologiczny, 6, 323-326.

Kleczkowski A.S., Myszka J., Solecki T. \& Stopa J., 1994 Krakowskie artezyjskie zdroje wód pitnych $z$ wapieni jury. Wydział Geologii, Geofizyki i Ochrony Środowiska AGH, Wydział Ochrony Środowiska, Urząd Wojewódzki, Kraków.

Kleczkowski A.S., Czop M., Motyka J. \& Rajchel L., 2009. Wpływ czynników geogenicznych i antropogenicznych na skład chemiczny wód podziemnych w Krakowie. Geologia, 35, 1, 117-128.

Kumar P.J.S., Delson P.D. \& Babu P.T., 2012. Appraisal of heavy metals in groundwater in Chennai using a HPI model. The Bulletin of Environmental Contamination and Toxicology, 89, 793-798.

LeChevallier M.W., Norton W.D. \& Lee R.G., 1991. Giardia and cryptosporidium in filtered drinking water supplies. Applied and Environmental Microbiology, 57, 9, 2617-2621.

Motyka J. \& Zuber A., 1992. Przepływ znaczników i polutantów przez węglanowe skały szczelinowate: 1 - Porowatość matrycy jako najważniejszy parametr. [in:] Kowalski J. (red.), Problemy hydrogeologiczne południowo-zachodniej Polski, Sudety, Wrocław, 103-109.

Moorcroft M.J., Davis J. \& Compton R.G., 2001. Detection and determination of nitrate and nitrite: a review. Talanta, 54, 5, 785-803.

Myszka R. \& Gołda J., 2003, Eksploatacja wód artezyjskich piętra jurajskiego w Krakowie. [in:] Piekarek-Jankowska H. \& Jaworska-Szulc B. (red.), Współczesne problemy hydrogeologii. T. 11, cz. 1, Wydział Budownictwa Wodnego i Inżynierii Środowiska Politechniki Gdańskiej, Gadańsk, 137-142.

Olszewski K., 1871, Rozbiór chemiczny wód studziennych i rzecznych krakowskich. Sprawozdania Komisji Fizjograficznej, 5, 131-162.

Osenbrück K., Weise S.M., Zuber A., Grabczak J. \& Ciezkowski W., 1993. Noble gas temperatures and ages of some glacial and burried brine waters in Poland. [in:] Isotope Techniques in the Study of Past and Current Environmental Changes in the Hydrosphere and Atmosphere, International Atomic Energy Agency, Vienna, 319-336. 
Prasad T.D. \& Danso-Amoako E., 2014. Influence of chemical and biological parameters on iron and manganese accumulation in water distribution networks. Procedia Engineering, 70, 1353-1361.

Rozporządzenie Ministra Środowiska $z$ dnia 15 listopada 2011 r. $w$ sprawie form $i$ sposobu prowadzenia monitoringu jednolitych części wód powierzchniowych i podziemnych. Dz. U. $2011 \mathrm{nr} 258$ poz. 1550 [Journal of Laws No 258, item 1550, of 15 November 2011, Minister of Environment, Poland].

Rozporządzenie Ministra Środowiska $z$ dnia 21 listopada 2013 r. zmieniające rozporzadzenie w sprawie form $i$ sposobu prowadzenia monitoringu jednolitych części wód powierzchniowych i podziemnych. Dz. U. 2013 poz. 1558 [Journal of Laws item 1558, of 21 November 2013, Minister of Environment, Poland].

Rozporzadzenie Ministra Zdrowia $z$ dnia 29 marca 2007 r. w sprawie jakości wody przeznaczonej do spożycia przez ludzi. Dz. U. $2007 \mathrm{nr} 61$ poz. 417 [Journal of Laws No 61, item 417, of 29 March 2007, Minister of Health, Poland].

Rozporzadzenie Ministra Zdrowia $z$ dnia 20 kwietnia 2010 r. zmieniajace rozporzadzenie w sprawie jakości wody przeznaczonej do spożycia przez ludzi. Dz. U. $2010 \mathrm{nr} 72$ poz. 466 [Journal of Laws No 72, item 466, of 20 April 2010, Minister of Health, Poland].

Wodociagi Krakowskie. Raport roczny 2013. [on-line:] http:// www.wodociagi.krakow.pl/upload/Subpages/raport 2013_11-07-2014_www_high.pdf) [access: 15.10.2014].

Rutkowski J., 1989. Budowa geologiczna regionu Krakowa. Przeglad Geologiczny, 37, 6, 302-308.
Sanepid (Sanitary-Facility, WSSE, Kraków): database for Małopolska region.

Szczepańska J., Kmiecik E. \& Drzymała M., 2008 Przyczyny zmian składu chemicznego wód artezyjskich ujmowanych w Zdroju Królewskim w Krakowie. [in:] Problemy wykorzystania wód podziemnych w gospodarce komunalnej: materiały na XVII sympozjum naukowo-techniczne pt. Zrównoważone gospodarowanie zasobami wód podziemnych na terenach przekształconych antropogenicznie: Częstochowa 17-18 kwietnia 2008 r., Częstochowa, 98-107

Woda i My: czasopismo Miejskiego Przedsiębiorstwa Wodociągów i Kanalizacji S.A. w Krakowie [issues from the years 2006-2013], [on-line:] http://www.mpwik.krakow. $\mathrm{pl} / 40 /$ Czasopismo-WODA-I-MY [access: 15.10.2014].

Zhang Y., Li F., Zhang Q., Li J. \& Liu Q., 2014. Tracing nitrate pollution sources and transformation in surface- and ground-waters using environmental isotopes. Science of the Total Environment, 490, 213-222.

Zuber A. \& Grabczak J., 1991. Badania izotopowe wód podziemnych Krakowa i okolic. [in:] Kleczkowski A. et al. (red.) Budowa geologiczna, warunki hydrogeologiczne i geotechniczne podłoża Krakowa. Konferencja naukowo-techniczna, Kraków, 51-58.

Zuber A., Weise S.M., Motyka J., Osenbrück K. \& Różański K., 2004. Age and flow pattern of groundwater in a Jurassic limestone aquifer and related Tertiary sands derived from combined isotope, noble gas and chemical data. Journal of Hydrology, 286, 87-112. 